\title{
The influence of allergic rhinoconjunctivitis on migraine disability in children
}

\author{
A influência da rinoconjuntivite alérgica sobre a incapacidade secundária à enxaqueca \\ em crianças
} Cassiano Mateus FORCELINI', Matheus RAMOS ${ }^{1}$, Isadora Ferraz dos SANTOS ${ }^{1}$, Gabriela BRACKMANN ${ }^{1}$,
Lucas Grumann BERNARDON ${ }^{1}$, Ana Paula Zanella CORBELLINI', Bruna Valentina PERIN ${ }^{1}$

\begin{abstract}
Migraine is a common condition in the pediatric population and causes a significant impact on the quality of life. Atopic disorders are some of the migraine comorbidities. Objective: We hypothesized that allergic rhinitis could aggravate migraine in the pediatric population. Methods: This cross-sectional study consecutively evaluated 90 pediatric outpatients (46 children 6-12 years of age; 44 adolescents up to 18 years of age) who sought medical assistance because of migraine at a general neurology clinic in Passo Fundo, RS, Brazil. They, and their parents, were given three questionnaires, to evaluate the diagnosis of current allergic rhinitis, allergic rhinoconjunctivitis and seasonal allergic rhinitis, as well as the disability caused by headache (ISAAC - International Study of Asthma and Allergies in Childhood; CARATkids - Control of Allergic Rhinitis and Asthma Test for Children; PedMIDAS - Pediatric Migraine Disability Assessment). The study was approved by the local ethics committee. Results: According to the ISAAC questionnaire, children with current allergic rhinoconjunctivitis in the last year showed higher scores on the PedMIDAS than those patients without atopy (median and interquartile range 26 [10-58] vs. 5 [1-13], $p=0.008$ ). A significant positive correlation of CARATkids scores with PedMIDAS scores was found ( $p=$ 0.007 , rho $=0.39$ ). After including other putative predictors of migraine disability (age, body mass index, time since onset of migraine) in a multiple regression analysis, only the scores on the CARATkids remained a significant independent variable correlated with PedMIDAS scores $\left(p=0.001 ; R=0.55 ; R^{2}=0.30\right.$ ). Conclusions: Current allergic rhinoconjunctivitis is related to enhanced disability caused by headache in childhood migraine.
\end{abstract}

Keywords: Migraine disorders; headache; child; rhinitis, allergic.

\section{RESUMO}

A enxaqueca é condição comum na população pediátrica e causa significativo impacto na qualidade de vida. Doenças atópicas estão entre as principais morbidades associadas. Objetivo: Teorizamos que a rinite alérgica possa agravar a enxaqueca na população pediátrica. Métodos: Este estudo transversal avaliou consecutivamente 90 pacientes pediátricos (46 crianças de 6 a 12 anos; 44 adolescentes até 18 anos) que procuraram assistência por enxaqueca em clínica neurológica de Passo Fundo, RS, Brasil. Eles e seus familiares responderam a três questionários para avaliar o diagnóstico de rinite alérgica, rinoconjuntivite alérgica e rinite alérgica sazonal, assim como a incapacidade causada pela cefaleia (ISAAC - International Study of Asthma and Allergies in Childhood; CARATkids - Control of Allergic Rhinitis and Asthma Test for Children; PedMIDAS - Pediatric Migraine Disability Assessment). A pesquisa foi aprovada por comitê de ética. Resultados: Crianças com rinoconjuntivite alérgica atual de acordo com o questionário ISAAC exibiram escores mais altos no PedMIDAS do que aquelas sem atopia (mediana e intervalo interquartil 26 [10-58] vs. 5 [1-13], p=0,008). Correlação significativamente positiva do escore no questionário CARATkids sobre o escore do PedMIDAS foi encontrada ( $p=0,007$, rho $=0,39$ ). Após inclusão de outros fatores teoricamente envolvidos com a incapacidade secundária à enxaqueca (idade, índice de massa corporal, tempo desde o início das crises de enxaqueca) em modelo de análise de regressão linear múltipla, apenas o escore do CARATkids permaneceu com significância como variável independente relacionada ao escore do PedMIDAS ( $\left.p=0,001 ; R=0,55 ; R^{2}=0,30\right)$. Conclusões: Rinoconjuntivite alérgica está relacionada ao aumento da incapacidade pela enxaqueca em crianças.

Palavras-chave: Transtornos da enxaqueca; cefaleia; crianças; rinite alérgica.

\footnotetext{
${ }^{1}$ Universidade de Passo Fundo, Faculdade de Medicina, Passo Fundo, RS, Brasil.

Cassiano Mateus Forcelini (iD) https://orcid.org/0000-0001-9614-1139; Matheus Ramos iD https://orcid.org/0000-0003-2953-181X; Isadora Ferraz dos Santos (iD https://orcid.org/0000-0002-2510-491X; Gabriela Brackmann iD https://orcid.org/0000-0001-8377-122X; Lucas Grumann Bernardon

(iD) https://orcid.org/0000-0001-6541-8617; Ana Paula Zanella Corbellini iD https://orcid.org/0000-0002-2506-580X; Bruna Valentina Perin iD https://orcid.org/0000-0002-6700-1433
}

Correspondence: Cassiano Mateus Forcelini; R. Teixeira Soares, 817; 99010-080 Passo Fundo RS, Brasil; E-mail: cmforcelini@gmail.com

Conflict of interest: There is no conflict of interest to declare.

Received 15 November 2018; Received in final form 07 March 2019; Accepted 03 April 2019. 
Migraine is a common condition, not only in adults, but also in the pediatric population. In fact, the estimated overall prevalence is $9.1 \%^{1}$, although it has been recognized that the frequency increases during the growing up period, from up to $10 \%$ in children to almost $28 \%$ in adolescents ${ }^{2}$. Headache causes a significant impact on the quality of life of these young populations ${ }^{3,4}$.

Childhood migraine is associated with several comorbidities, including atopic diseases ${ }^{5,6}$. Indeed, asthma and hay fever were more common in a large series of American children and adolescents with headache than among those without headache ${ }^{5}$. Other studies worldwide have also emphasized the prominent frequency of atopic disease in young migraineurs ${ }^{7,8}$, including allergic rhinitis, rhinoconjunctivitis and seasonal rhinitis ${ }^{7}$. A Turkish survey among children and adolescents complaining of headache demonstrated a higher prevalence of atopic disorders in migraine than in tension-type headache sufferers, as well as in migraine with aura patients than in those without aura ${ }^{9}$. Conversely, the prevalence of both headache and migraine in atopic children was found to be higher than expected in another study ${ }^{10}$.

Although this relationship may be bidirectional, two longitudinal surveys from Taiwan have reported a higher risk of developing migraine in atopic children in comparison with nonatopic children, especially those with allergic rhinitis $^{11,12}$, suggesting a role of the immune system in the manifestation of migraine. On the other hand, anti-asthmatic and anti-allergic therapies were associated with decreased risk of migraine in children and adolescents ${ }^{8}$.

The issue about the actual relationship between atopic diseases and migraine is far from being solved, as are its putative mechanisms. In this scenario, an unanswered question is whether current allergic rhinitis is capable of enhancing the disability of migraine in children and adolescents. This was the purpose of our survey.

\section{METHODS}

The sample of this cross-sectional study comprised 91 patients (47 children from 6-12 years of age; 44 adolescents older than 12 and up to 18 years old) with migraine with or without aura, diagnosed according to the International Classification of Headache Disorders, $3^{\text {rd }}$ edition (beta version $)^{13}$. Participants were consecutively evaluated in the Instituto de Neurologia e Neurocirurgia, an outpatient neurological clinic of Passo Fundo, RS, Brazil, from November 2016 to June 2018. Patients were invited to participate in the study and gave their written informed consent, accompanied by parents or responsible relatives who also agreed. Only one child declined to participate at the beginning of the procedures, rendering a final figure of 90 patients (46 children; 44 adolescents). This research was conducted in accordance with the Declaration of Helsinki and was approved by the Ethics Committee of Universidade de Passo Fundo.

Demographic and clinical data were obtained during interviews with patients and their parents/relatives and included the number of headache days per month during the previous three months, the average severity of headache based on a 0-10 visual analog scale ${ }^{14}$, and the time since onset of migraine-variables that could theoretically be related to migraine disability - as well as the body mass index obtained during the patient's physical examination. Afterwards, patients and their parents/relatives answered the following questionnaires: 1) Validated Portuguese version of the International Study of Asthma and Allergies in Childhood (ISAAC) for perennial and seasonal allergic rhinitis questionnaire ${ }^{15}$; 2) Control of Allergic Rhinitis and Asthma Test for Children (CARATkids), originally developed in Portuguese and validated in Brazil ${ }^{16}$; 3 ) The Pediatric Migraine Disability Assessment (PedMIDAS) translated and adapted to Brazilian Portuguese ${ }^{17}$.

The PedMIDAS instrument is a six-item questionnaire that measures headache-related disability through a score (the higher the score, the worse the disability) of the sum of the days the patient had any disability caused by migraine in the three months prior. The CARATkids is a questionnaire divided into two parts-one for the patient and the other for the parents/relatives-that investigates current symptoms of asthma and allergic rhinitis in the two weeks prior and renders a score of positive answers to 13 questions. Because patients with a diagnosis of asthma were excluded from the study, any positive reply on the CARATkids related to rhinitis symptoms was considered to be indicative of the presence of current allergic rhinitis, in the absence of an infection of the upper airways. The sum of positive answers on the CARATkids also rendered a final score. The CARATkids questionnaire was applied only to the younger children, because it was not originally designed for adolescents.

Current allergic rhinitis was defined as having a runny, itchy or stuffy nose without a cold in the last 12 months according to the ISAAC questionnaire, while the report of nasal compromise associated with eye symptoms was considered to be allergic rhinoconjunctivitis. Seasonal allergic rhinitis was diagnosed if the former symptoms were accompanied by a positive reply to the modified last question in the Portuguese version of the ISAAC questionnaire (Have you ever had allergic rhinitis related to pollen [during the spring]?). The diagnoses of allergic rhinitis, allergic rhinoconjunctivitis and seasonal allergic rhinitis according to the ISAAC questionnaire were not mutually exclusive.

\section{Statistics}

A sample size (with a $80 \%$ power calculation) was estimated with the aid of WinPepi version 11.50 software (J. H. 
Abramson) based on a previous study that correlated allergic sensitization characterized by high blood levels of IgE with greater disability due to headache in 100 migraine patients ${ }^{18}$.

Quantitative data are presented as mean and standard deviation or, when otherwise stated, median and interquartile range. Categorical data are described as percentage. The Student's t-test was used to compare quantitative variables, except in the case of asymmetrical distribution that required the Mann-Whitney U test. The qui-square test was employed for the comparison of proportions. Spearman's correlation and multiple regression analysis (Pearson's " $r$ " statistics) were undertaken to correlate the CARATkids scores and plausible confounding factors with the scores obtained from the PedMIDAS questionnaire. Analyses were performed with the commercially-available Statistical Package for the Social Sciences (SPSS) version 16.0 (SPSS Inc, Chicago, IL, USA) and GraphPad Prism version 5.00 (GraphPad Software Inc, San Diego, CA, USA). Statistical significance was assumed when a two-tailed p-value $\leq 0.05$.

\section{RESULTS}

Demographic and clinical characteristics of the sample are shown in Table 1. Most were Caucasian, reflecting the local ethnic composition in south Brazil. The prominence of females was expected from the epidemiology of migraine sufferers, especially among adolescents.

Table 1. Demographic and clinical characteristics of the sample $(n=90)$.

\begin{tabular}{|c|c|c|}
\hline Characteristics & $\begin{array}{l}\text { Children } \\
(n=46)\end{array}$ & $\begin{array}{l}\text { Adolescents } \\
\quad(n=44)\end{array}$ \\
\hline Female & $63.0 \%$ & $79.5 \%$ \\
\hline Male & $37.0 \%$ & $20.5 \%$ \\
\hline White & $93.5 \%$ & $90.9 \%$ \\
\hline Age (years) & $8.9 \pm 2.1$ & $15.3 \pm 1.7$ \\
\hline Body mass index $\left(\mathrm{kg} / \mathrm{m}^{2}\right)$ & $17.9 \pm 4.0$ & $21.3 \pm 4.0$ \\
\hline Migraine with aura & $6.5 \%$ & $18.2 \%$ \\
\hline Migraine without aura & $93.5 \%$ & $81.8 \%$ \\
\hline Days with headache (per month) & $6.8 \pm 6.7$ & $10.7 \pm 7.6$ \\
\hline $\begin{array}{l}\text { Severity of headache } \\
\text { (on } 0-10 \text { analogical scale) }\end{array}$ & $6.7 \pm 2.2$ & $6.8 \pm 1.5$ \\
\hline $\begin{array}{l}\text { Time since onset of migraine } \\
\text { (years) }\end{array}$ & $1.7(1-3)^{*}$ & $4.6 \pm 3.1$ \\
\hline PedMIDAS score & $10(4-28.5) *$ & $39.6 \pm 37.9$ \\
\hline CARATkids score & $4(0-6.5) *$ & - \\
\hline Allergic rhinitis & $58.7 \%$ & $65.9 \%$ \\
\hline Allergic rhinoconjunctivitis & $43.5 \%$ & $50.0 \%$ \\
\hline Seasonal allergic rhinitis & $41.3 \%$ & $36.4 \%$ \\
\hline
\end{tabular}

Table 2 shows the comparisons of quantitative variables between children with or without current allergic rhinitis, allergic rhinoconjunctivitis, and seasonal allergic rhinitis according to the ISAAC questionnaire, while Table 3 shows the correspondent figures for adolescents.

There were no significant differences in the proportion of migraine with aura/without aura diagnosis between the groups of patients with and without current allergic rhinitis $(p=0.59)$, allergic rhinoconjunctivitis $(p=0.34)$, and seasonal allergic rhinitis $(\mathrm{p}=0.31)$ according to the ISAAC questionnaire.

We also performed Spearman's correlation on each of the following variables in the children's PedMIDAS scores: age, body mass index, time since onset of migraine and the scores on the CARATkids. A significant positive correlation was found only for scores on the CARATkids ( $p=0.07$; rho $=0.39$ ). After including the aforementioned putative predictors of migraine disability in a multiple regression analysis (Pearson's "r" statistics), in a stepwise manner, only the score on the CARATkids remained significant as an independent variable related to the PedMIDAS scores $(p=0.01)$, with moderate power $\left(R=0.55 ; R^{2}=0.30\right)$.

\section{DISCUSSION}

Several studies have correlated allergic rhinitis with migraine in childhood, pointing either to a prominent prevalence of the latter in patients with atopy ${ }^{10}$, or to a higher than expected frequency of allergic conditions in migraineurs ${ }^{5,7-9}$. The susceptibility for developing migraine in children suffering from allergic rhinitis was also suggested ${ }^{11,12}$.

However, to our knowledge, this was the first study that proposed to preliminarily investigate the hypothesis that current allergic rhinitis could aggravate migraine in the pediatric population, leading to enhanced disability caused by headache. In line with such expectations, we found positive results in the group aged 6-12 years old. Among children attending the migraine outpatient clinic, those with current allergic rhinoconjunctivitis during the last 12 months according to the ISAAC questionnaire had higher scores on the PedMIDAS than children without atopy. The positive correlation and regression of the CARATkids scores on the PedMIDAS scores among children reinforces this finding, even after controlling for plausible confounding factors. Nevertheless, comparison of scores on the PedMIDAS from adolescent migraine patients with or without current allergic rhinitis was negative.

In this setting, two main explanations are proposed. The first relies on the possibility that the immune system may be more active in childhood than in adolescence, reflecting the initial step of a process that will accelerate in the elderly, called immunosenescense. An example of this biological process is the decrease of total and specific serum IgE with age in 
Table 2. Comparison of clinical data from children with migraine $(n=46)$ considering the presence or absence of current allergic rhinitis, allergic rhinoconjunctivitis and seasonal allergic rhinitis according to the ISAAC questionnaire.

\begin{tabular}{|c|c|c|c|}
\hline Variables & Presence of allergic rhinitis $(n=27)$ & Absence of allergic rhinitis $(n=19)$ & $\mathrm{p}$-value \\
\hline Age & $8.7 \pm 2.2$ & $9.2 \pm 2.0$ & 0.51 \\
\hline Body mass index $\left(\mathrm{kg} / \mathrm{m}^{2}\right)$ & $17.8 \pm 4.0$ & $18.0 \pm 4.1$ & 0.89 \\
\hline Days with headache (per month) & $6.2 \pm 6.3$ & $7.6 \pm 7.3$ & 0.50 \\
\hline $\begin{array}{l}\text { Severity of headache (on 0-10 analogical } \\
\text { scale) }\end{array}$ & $6.4 \pm 2.4$ & $7.1 \pm 1.8$ & 0.29 \\
\hline Time since onset of migraine (years)* & $1(0.5-3)$ & $2(1-3)$ & 0.21 \\
\hline \multirow[t]{2}{*}{ PedMIDAS* } & $13(4-36)$ & $9(2-20)$ & 0.13 \\
\hline & $\begin{array}{c}\text { Presence of allergic } \\
\text { rhinoconjunctivitis }(n=20)\end{array}$ & $\begin{array}{l}\text { Absence of allergic } \\
\text { rhinoconjunctivitis }(n=26)\end{array}$ & p-value \\
\hline Age & $8.8 \pm 2.1$ & $9.0 \pm 2.1$ & 0.67 \\
\hline Body mass index $\left(\mathrm{kg} / \mathrm{m}^{2}\right)$ & $18.5 \pm 4.1$ & $17.5 \pm 4.0$ & 0.53 \\
\hline Days with headache (per month) & $7.8 \pm 6.6$ & $6.0 \pm 6.7$ & 0.37 \\
\hline $\begin{array}{l}\text { Severity of headache (on 0-10 analogical } \\
\text { scale) }\end{array}$ & $6.9 \pm 2.2$ & $6.6 \pm 2.2$ & 0.67 \\
\hline Time since onset of migraine (years)* & $2(0.7-3)$ & $1(1-2.7)$ & 0.83 \\
\hline \multirow[t]{2}{*}{ PedMIDAS* } & $26(10-58)$ & $5(1-13)$ & 0.008 \\
\hline & $\begin{array}{c}\text { Presence of seasonal allergic } \\
\text { rhinitis }(n=19)\end{array}$ & $\begin{array}{l}\text { Absence of seasonal allergic rhinitis } \\
\qquad(n=27)\end{array}$ & $\mathrm{p}$-value \\
\hline Age & $8.7 \pm 2.5$ & $9.1 \pm 1.9$ & 0.56 \\
\hline Body mass index $\left(\mathrm{kg} / \mathrm{m}^{2}\right)$ & $17.7 \pm 3.8$ & $18.0 \pm 4.2$ & 0.85 \\
\hline Days with headache (per month) & $6.2 \pm 6.9$ & $7.2 \pm 6.6$ & 0.63 \\
\hline $\begin{array}{l}\text { Severity of headache (on 0-10 analogical } \\
\text { scale) }\end{array}$ & $6.8 \pm 2.2$ & $6.7 \pm 2.2$ & 0.92 \\
\hline Time since onset of migraine (years)* & $1(0.5-3)$ & $2(1-3)$ & 0.44 \\
\hline PedMIDAS* & $13(4-36)$ & $9(4-24)$ & 0.37 \\
\hline
\end{tabular}

PedMIDAS: Pediatric Migraine Disability Assessment.Data are shown as mean \pm standard deviation or, when otherwise stated (*), median and interquartile range. Comparisons performed with Student's t-test or Mann-Whitney U test, the latter in case of asymmetric distribution.

Table 3. Comparison of clinical data from adolescents with migraine $(n=44)$ considering the presence or absence of current allergic rhinitis, allergic rhinoconjunctivitis and seasonal allergic rhinitis according to the ISAAC questionnaire.

\begin{tabular}{|c|c|c|c|}
\hline Variables & Presence of allergic rhinitis $(n=29)$ & Absence of allergic rhinitis $(n=15)$ & $p$-value \\
\hline Age & $15.4 \pm 1.6$ & $15.0 \pm 1.9$ & 0.48 \\
\hline Body mass index $\left(\mathrm{kg} / \mathrm{m}^{2}\right)$ & $20.8 \pm 3.5$ & $22.2 \pm 4.9$ & 0.32 \\
\hline Days with headache (per month) & $11.7 \pm 8.2$ & $8.7 \pm 5.9$ & 0.22 \\
\hline $\begin{array}{l}\text { Severity of headache (on } 0-10 \text { analogical } \\
\text { scale) }\end{array}$ & $7.0 \pm 1.4$ & $6.6 \pm 1.7$ & 0.40 \\
\hline Time since onset of migraine (years) & $5.0 \pm 3.4$ & $3.7 \pm 2.4$ & 0.18 \\
\hline \multirow[t]{2}{*}{ PedMIDAS } & $43.1 \pm 42.3$ & $32.8 \pm 27.6$ & 0.39 \\
\hline & $\begin{array}{c}\text { Presence of allergic } \\
\text { rhinoconjunctivitis }(n=22)\end{array}$ & $\begin{array}{l}\text { Absence of allergic } \\
\text { rhinoconjunctivitis }(n=22)\end{array}$ & p-value \\
\hline Age & $15.5 \pm 1.5$ & $15.0 \pm 1.8$ & 0.29 \\
\hline Body mass index $\left(\mathrm{kg} / \mathrm{m}^{2}\right)$ & $21.3 \pm 3.3$ & $21.2 \pm 4.7$ & 0.91 \\
\hline Days with headache (per month) & $12.6 \pm 9.1$ & $8.8 \pm 5.1$ & 0.10 \\
\hline $\begin{array}{l}\text { Severity of headache (on 0-10 analogical } \\
\text { scale) }\end{array}$ & $7.2 \pm 1.3$ & $6.5 \pm 1.7$ & 0.17 \\
\hline Time since onset of migraine (years) & $5.6 \pm 3.5$ & $3.5 \pm 2.3$ & 0.02 \\
\hline \multirow[t]{2}{*}{ PedMIDAS } & $48.2 \pm 46.6$ & $33.9 \pm 24.7$ & 0.13 \\
\hline & $\begin{array}{c}\text { Presence of seasonal allergic } \\
\text { rhinitis }(n=16)\end{array}$ & $\begin{array}{l}\text { Absence of seasonal allergic rhinitis } \\
\qquad(n=28)\end{array}$ & p-value \\
\hline Age & $15.4 \pm 1.5$ & $15.2 \pm 1.8$ & 0.73 \\
\hline Body mass index $\left(\mathrm{kg} / \mathrm{m}^{2}\right)$ & $20.9 \pm 3.7$ & $21.4 \pm 4.2$ & 0.69 \\
\hline Days with headache (per month) & $12.5 \pm 8.4$ & $9.7 \pm 7.0$ & 0.25 \\
\hline $\begin{array}{l}\text { Severity of headache (on } 0-10 \text { analogical } \\
\text { scale) }\end{array}$ & $7.1 \pm 1.5$ & $6.7 \pm 1.6$ & 0.41 \\
\hline Time since onset of migraine (years) & $5.2 \pm 3.8$ & $4.3 \pm 2.7$ & 0.37 \\
\hline PedMIDAS & $51.0 \pm 37.5$ & $33.0 \pm 37.2$ & 0.13 \\
\hline
\end{tabular}


patients with allergic rhinitis ${ }^{19}$, and the more bothersome rhinoconjunctivitis in children than in adolescents and adults ${ }^{20}$.

An alternative approach to the finding of positive results in children but which was negative in adolescents would be an insufficient sample size in the latter group. This may be seen as the first limitation of the study, even though it would not confront the aforementioned theory of an initial immunosenescense, taking into account the remarkable differences obtained on the PedMIDAS scores in the group of children, which was almost the same size as the adolescent group. Thus, even the small sample rendered prominent positive results in children, probably reflecting an active biological effect of allergic rhinoconjunctivitis that may have greater magnitude than found among adolescents.

The second issue is about the reputed mechanisms underlying the clinical worsening of childhood migraine by current allergic rhinoconjunctivitis. Both conditions may share common neural pathways and immune mediators ${ }^{21}$. Nasal congestion and discharge, sneezing, and eye itching and watering require sensitive trigeminal transmission, a system that ultimately is involved in migraine. In addition, the inflammatory processes that take place in allergic rhinoconjunctivitis could also predispose the individual to aggravation of migraine through activation of immune responses.

We recognize that the lack of a pathophysiological investigation regarding the immune mechanism underlying the aggravation of migraine by allergic rhinoconjunctivitis is an important limitation of our study. Several abnormalities on parameters of cellular and humoral immunity have been reported in migraine ${ }^{22,23}$, but those related to allergic sensitization could be the first candidates to be examined in future research about the mechanisms that cause the worsening of childhood migraine by allergic rhinitis. In this setting, a deeper investigation in terms of the specific diagnosis of allergic sensitizations, such as a confirmation of the aforementioned diagnoses by serologic or skin tests, would be desirable in future studies.

Another limitation that must be stressed is the fact that all patients included in the present survey suffered enough to make them seek medical assistance due to headache. This may not reflect the real scenario in the general population, but only in children with more severe migraine.

The treatment of migraine in childhood does not have a high quality of evidence ${ }^{24}$, a fact that justifies the search for new perspectives on managing this troubling and sometimes disabling condition. In this setting, investigating the ways of controlling a comorbid trigger of migraine is desirable. An initial suggestion has been made that anti-asthmatic or anti-allergic therapies may be associated with decreased risk of migraine in children and adolescents ${ }^{8}$. If further studies reinforce the role of current rhinoconjunctivitis in worsening migraine, the future enterprise of a clinical trial for treatment of allergic rhinitis, targeting one of the most important causes of headache in childhood ${ }^{25}$, would seem acceptable.

Our results suggest that current allergic rhinoconjunctivitis is related to enhanced disability caused by headache in childhood migraine. Further studies about the pathophysiology of this influence, as well as on the helpfulness of managing atopic disorders for ameliorating migraine children, are needed.

\section{References}

1. Wöber-Bingöl C. Epidemiology of migraine and headache in children and adolescents. Curr Pain Headache Rep. 2013 Jun;17(6):341. https://doi.org/10.1007/s11916-013-0341-z

2. Hershey AD. What is the impact, prevalence, disability, and quality of life of pediatric headache? Curr Pain Headache Rep. 2005 Oct;9(5):341-4. https://doi.org/10.1007/s11916-005-0010-y

3. Arruda MA, Bigal ME. Behavioral and emotional symptoms and primary headaches in children: a population-based study. Cephalalgia. 2012 Nov;32(15):1093-100. https://doi.org/10.1177/0333102412454226

4. Kernick D, Reinhold D, Campbell JL. Impact of headache on young people in a school population. Br J Gen Pract. 2009 Sep;59(566):67881. https://doi.org/10.3399/bjgp09X454142

5. Lateef TM, Merikangas KR, He J, Kalaydjian A, Khoromi S, Knight E, et al. Headache in a national sample of American children: prevalence and comorbidity. J Child Neurol. 2009 May;24(5):536-43. https://doi.org/10.1177/0883073808327831

6. Bellini B, Arruda M, Cescut A, Saulle C, Persico A, Carotenuto $\mathrm{M}$, et al. Headache and comorbidity in children and adolescents. J Headache Pain. 2013 Sep;14(1):79. https://doi.org/10.1186/1129-2377-14-79

7. Muñoz-Jareño N, Fernández-Mayoralas DM, Martínez-Cervell C, Campos-Castelló J. [Relationship between migraine and atopy in childhood: a retrospective case-control study]. Rev Neurol. 2011 Dec;53(12):713-20.
8. Aupiais C, Wanin S, Romanello S, Spiri D, Moretti R, Boizeau P, et al. Association between migraine and atopic diseases in childhood: a potential protective role of anti-allergic drugs. Headache. 2017 Apr;57(4):612-24. https://doi.org/10.1111/head.13032

9. Özge A, Öksüz N, Ayta S, Uluduz D, Yıldırım V, Toros F, et al. Atopic disorders are more common in childhood migraine and correlated headache phenotype. Pediatr Int. 2014 Dec;56(6):868-72. https://doi.org/10.1111/ped.12381

10. Mortimer MJ, Kay J, Gawkrodger DJ, Jaron A, Barker DC. The prevalence of headache and migraine in atopic children: an epidemiological study in general practice. Headache. 1993 Sep;33(8):427-31. https://doi.org/10.1111/j.1526-4610.1993.hed3308427.x

11. Wang IC, Tsai JD, Lin CL, Shen TC, Li TC, Wei CC. Allergic rhinitis and associated risk of migraine among children: a nationwide population-based cohort study. Int Forum Allergy Rhinol. 2016 Mar;6(3):322-7. https://doi.org/10.1002/alr.21654

12. Wei CC, Lin CL, Shen TC, Chen AC. Children with allergic diseases have an increased subsequent risk of migraine upon reaching school age. J Investig Med. 2018 Oct;66(7):1064-8. https://doi.org/10.1136/jim-2018-000715

13. International Headache Society. The International Classification of Headache Disorders, 3rd edition (beta version). Cephalalgia. 2013;33(9):629-808. https://doi.org/10.1177/0333102413485658 
14. Hawker GA, Mian S, Kendzerska T, French M. Measures of adult pain: Visual Analog Scale for Pain (VAS Pain), Numeric Rating Scale for Pain (NRS Pain), McGill Pain Questionnaire (MPQ), ShortForm McGill Pain Questionnaire (SF-MPQ), Chronic Pain Grade Scale (CPGS), Short Form-36 Bodily Pain Scale (SF-36 BPS), and Measure of Intermittent and Constant Osteoarthritis Pain (ICOAP). Arthritis Care Res (Hoboken). 2011 Nov;63(S11 Suppl 11):S240-52. https://doi.org/10.1002/acr.20543

15. Esteves PC, Trippia SG, Rosário Filho NA, Caleffe LG. Validation of ISAAC questionnaire for perennial and seasonal allergic rhinitis in Curitiba. Rev Bras Alerg Imunopatol. 1999;22(4):106-13.

16. Amaral R, Carneiro AC, Wandalsen G, Fonseca JA, Sole D. Control of Allergic Rhinitis and Asthma Test for Children (CARATKids): validation in Brazil and cutoff values. Ann Allergy Asthma Immunol. 2017 May;118(5):551-556.e2. https://doi.org/10.1016/j.anai.2017.02.007

17. Sampaio Rocha-Filho PA, Hershey AD. Pediatric Migraine Disability Assessment (PedMIDAS): translation into Portuguese and cross-cultural adaptation. Headache. 2017 Oct;57(9):1409-15. https://doi.org/10.1111/head.13159

18. Rosario D, Pinto G. Role of gender and serum immunoglobulin E (IGE) levels on severity of migraine. J Clin Diagn Res. 2014 Feb;8(2):57-8. https://doi.org/10.7860/JCDR/2014/7516.4007

19. Mediaty A, Neuber K. Total and specific serum IgE decreases with age in patients with allergic rhinitis, asthma and insect allergy but not in patients with atopic dermatitis. Immun Ageing. 2005 May;2(1):9. https://doi.org/10.1186/1742-4933-2-9

20. Devillier P, Bousquet PJ, Grassin-Delyle S, Salvator H, Demoly P, Bousquet J, et al. Comparison of outcome measures in allergic rhinitis in children, adolescents and adults. Pediatr Allergy Immunol. 2016 Jun;27(4):375-81. https://doi.org/10.1111/pai.12561

21. Güvenç IA, Acar M, Muluk NB, Kucukcan NE, Cingi C. Is there an association between migraine and allergic rhinitis? Ear Nose Throat J. 2017 Jun;96(6):E18-23. https://doi.org/10.1177/014556131709600604

22. Kemper RH, Meijler WJ, KorfJ, Ter Horst GJ. Migraine and function of the immune system: a meta-analysis of clinical literature published between 1966 and 1999. Cephalalgia. 2001 Jun;21(5):549-57. https://doi.org/10.1046/j.1468-2982.2001.00196.x

23. Bruno PP, Carpino F, Carpino G, Zicari A. An overview on immune system and migraine. Eur Rev Med Pharmacol Sci. 2007 Jul-Aug;11(4):245-8.

24. Orr SL, Kabbouche MA, O'Brien HL, Kacperski J, Powers SW, Hershey AD. Paediatric migraine: evidence-based management and future directions. Nat Rev Neurol. 2018 Sep;14(9):515-27. https://doi.org/10.1038/s41582-018-0042-7

25. Blume HK. Childhood headache: a brief review. Pediatr Ann. 2017 Apr;46(4):e155-65. https://doi.org/10.3928/19382359-20170321-02 